\title{
An easy $\alpha$-glycosylation methodology for the synthesis and stereochemistry of mycoplasma a-glycolipid antigens
}

\author{
Yoshihiro Nishida ${ }^{* 1}$, Yuko Shingu ${ }^{2}$, Yuan Mengfei ${ }^{1}$, Kazuo Fukuda ${ }^{1}$, \\ Hirofumi Dohi ${ }^{1}$, Sachie Matsuda ${ }^{2}$ and Kazuhiro Matsuda ${ }^{2}$
}

\section{Full Research Paper}

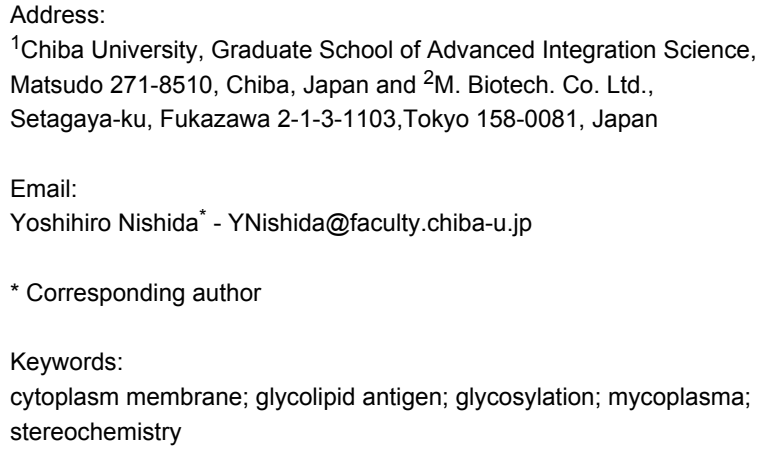

${ }^{1}$ Chiba University, Graduate School of Advanced Integration Science, Matsudo 271-8510, Chiba, Japan and ${ }^{2} \mathrm{M}$. Biotech. Co. Ltd., Setagaya-ku, Fukazawa 2-1-3-1103,Tokyo 158-0081, Japan

Email:

Yoshihiro Nishida* - YNishida@faculty.chiba-u.jp

* Corresponding author

Keywords:

cytoplasm membrane; glycolipid antigen; glycosylation; mycoplasma; stereochemistry

\author{
Beilstein J. Org. Chem. 2012, 8, 629-639. \\ doi:10.3762/bjoc.8.70 \\ Received: 15 January 2012 \\ Accepted: 28 March 2012 \\ Published: 24 April 2012 \\ This article is part of the Thematic Series "Synthesis in the \\ glycosciences II". \\ Guest Editor: T. K. Lindhorst \\ (c) 2012 Nishida et al; licensee Beilstein-Institut. \\ License and terms: see end of document.
}

\begin{abstract}
Mycoplasma fermentans possesses unique $\alpha$-glycolipid antigens (GGPL-I and GGPL-III) at the cytoplasm membrane, which carry a phosphocholine group at the sugar primary $(6-\mathrm{OH})$ position. This paper describes a practical synthetic pathway to a GGPL-I homologue $\left(\mathrm{C}_{16: 0}\right)$ and its diastereomer, in which our one-pot $\alpha$-glycosylation method was effectively applied. The synthetic GGPL-I isomers were characterized with ${ }^{1} \mathrm{H}$ NMR spectroscopy to determine the equilibrium among the three conformers $(g g, g t, t g)$ at the acyclic glycerol moiety. The natural GGPL-I isomer was found to prefer $g t(54 \%)$ and $g g(39 \%)$ conformers around the lipid tail, while adopting all of the three conformers with equal probability around the sugar position. This property was very close to what we have observed with respect to the conformation of phosphatidylcholine (DPPC), suggesting that the Mycoplasma glycolipids GGPLs may constitute the cytoplasm fluid membrane together with ubiquitous phospholipids, without inducing stereochemical stress.
\end{abstract}

\section{Introduction}

Mycoplasmas constitute a family of gram-positive microbes lacking rigid cell walls. They are suspected to be associated with human immune diseases, in either direct or indirect ways, although the molecular mechanism is not fully understood [1]. In recent biochemical studies, Mycoplasma outer-membrane lipoproteins [2,3] and glycolipids [4-6] are thought to serve not only as the main antigens but also as probable pathogens. Also in our research team, Matsuda et al. [7-10] isolated a new class of $\alpha$-glycolipid antigens (GGPL-I and GGPL-III, Figure 1) from M. fermentans. Another $\alpha$-glycolipid (MfGL-II), which has a chemical structure very close to GGPL-III, was identified and characterized by other groups [11-14]. 


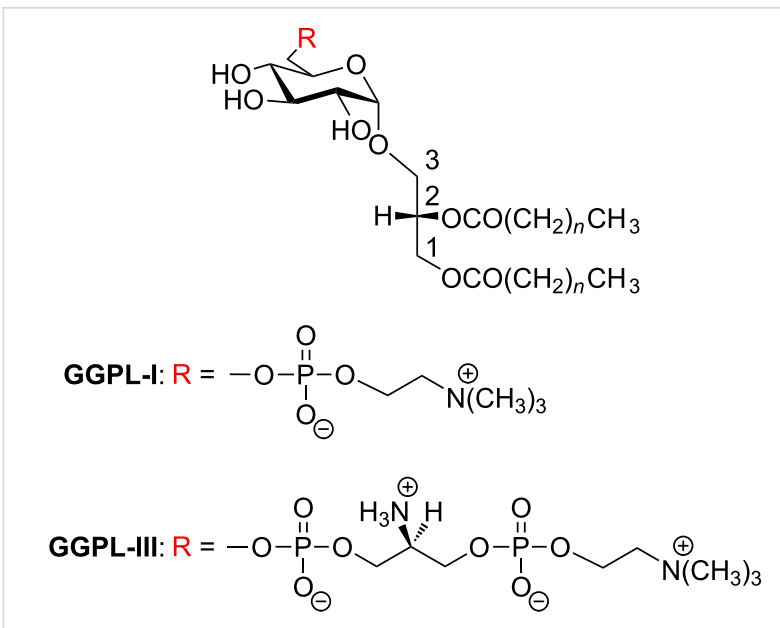

Figure 1: Absolute chemical structures of $M$. fermentans a-glycolipid antigens, GGPL-I and GGPI-III (GGPL: Glycosyl-sn-glycerophospholipid).

Absolute chemical structures of GGPL-I [15] and GGPL-III [16] have already been established by chemical syntheses of stereoisomers; these $\alpha$-glycolipids have a common chemical backbone of 3-O-( $\alpha$-D-glucopyranosyl)-sn-glycerol carrying phosphocholine at the sugar primary $(6-\mathrm{OH})$ position. The fatty acids at the glycerol moiety are saturated, namely palmitic acid $\left(\mathrm{C}_{16: 0}\right)$ and stearic acid $\left(\mathrm{C}_{18: 0}\right)$. GGPL-I has a structural feature analogous to 1,2-di- $O$-palmitoyl phosphatidylcholine (DPPC) as a ubiquitous cell membrane phospholipid. Apparently, GGPLs are amphiphilic compounds that can form certain self-assembled structures under physiological conditions $[12,13]$ and may give physicochemical stress on the immune system of the host [17]. In fact, our research team has proven that these $\alpha$-glycolipid antigens have certain pathogenic functions $[18,19]$.
In order to exploit their biological functions in detail, it is necessary to obtain these $\alpha$-glycolipids in sufficient amounts. Thus, both genetic [20-22] and chemical synthetic approaches $[23,24]$ are being followed, although no practical way has yet been established. In this paper, we report a chemical access to both a natural GGPL-I homologue $\left(\mathrm{C}_{16: 0}\right)$ and its diastereomer I-a and I-b, in which our one-pot $\alpha$-glycosylation methodology $[25,26]$ is effectively applied. The two GGPL-I isomers prepared thereby were characterized with ${ }^{1} \mathrm{H}$ NMR spectroscopy, in terms of configuration and conformation at the asymmetric glycerol moiety.

\section{Results and Discussion A practical synthetic access to GGPL-I homo- logues}

GGPL-I provides two key asymmetric centers to be controlled, literally, in the synthetic pathway. One is the configuration at the chiral glycerol moiety, and another is the sugar $\alpha$-glycoside linkage. In former synthetic works on 3-O-( $\alpha$-D-glycopyranosyl)-sn-glycerol [27-30], chiral 1,2-O-isopropylidene-sn-glycerol has often been employed [29,30] as the acceptor substrate for different $\alpha$-glycosylation reactions. In this case, however, attention should be paid to the acid-catalyzed migration of the dimethylketal group [23,29-31]. In our synthetic pathway, chiral $(S)$ - or $(R)$-glycidol is employed as an alternative source of the chiral glycerol to circumvent this problem. In an established synthetic approach, 6-O-acetyl-2,3,4-tri- $O$-benzyl protected sugar 1 [23] is used as the donor and treated with a reagent combination of $\mathrm{CBr}_{4}$ and $\mathrm{Ph}_{3} \mathrm{P}$ (Appel-Lee reagent) in either $\mathrm{CH}_{2} \mathrm{Cl}_{2}$ or DMF solvent, or a mixture of the two (Scheme 1). For the reaction in $\mathrm{CH}_{2} \mathrm{Cl}_{2}, N, N, N$ ', $N$ '-tetramethylurea (TMU) is added after in situ formation of $\alpha$-glycosyl bromide 2 , which

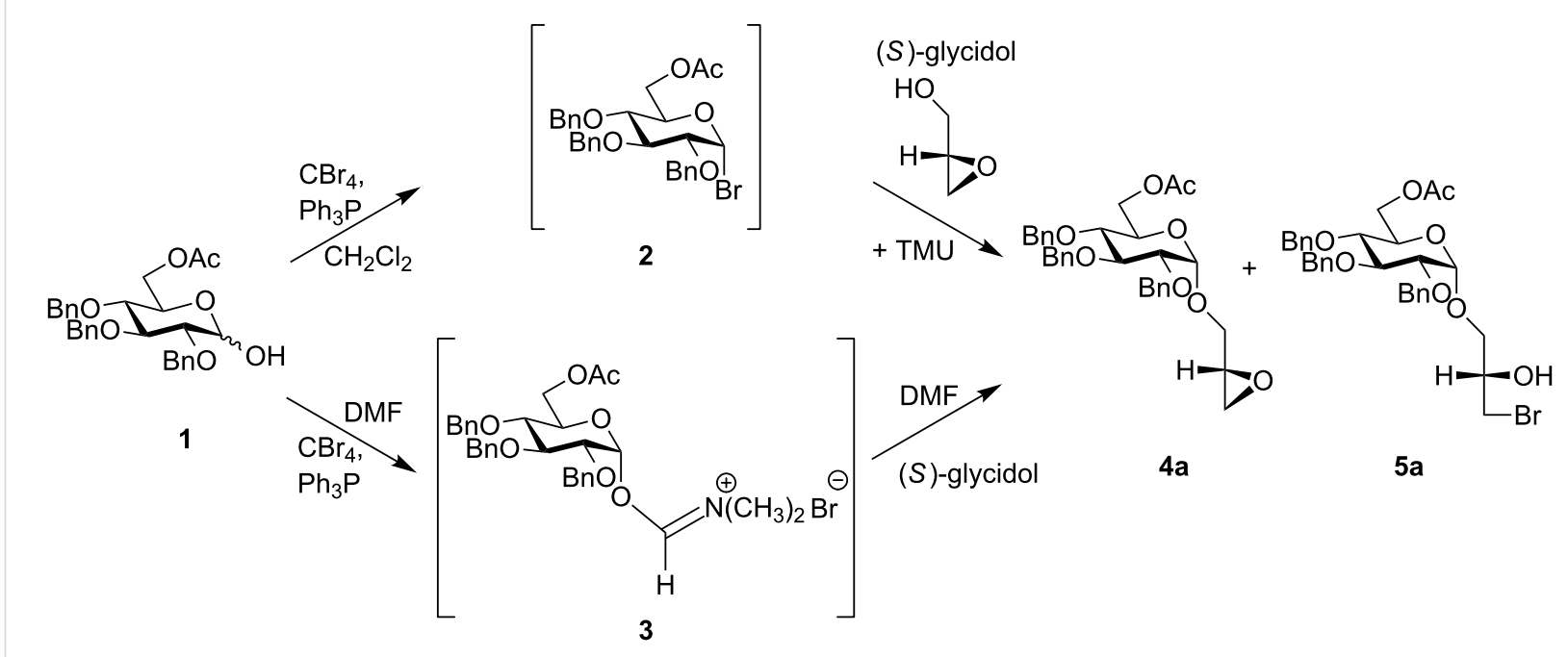

Scheme 1: An established synthetic pathway to $\alpha$-glycosyl-sn-glycerols $4 \mathbf{a}$ and $\mathbf{5 a}$. A reagent combination of $\mathrm{CBr}_{4}$ and $\mathrm{Ph}_{3} \mathrm{P}\left(\mathrm{Appel}_{-\mathrm{Lee}}\right.$ reagent) is utilized in either $\mathrm{CH}_{2} \mathrm{Cl}_{2}$ or DMF as solvent. 
equilibrates with a more reactive $\beta$-glycosyl bromide species [32]. In the pathway using DMF, the $\alpha$-glycosylation is routed via $\alpha$-glycosyl cationic imidate 3 , which was predicted in former studies [33] and evidenced in our preceding NMR and MS study $[25,26]$.

The reaction between 1 and $(S)$-glycidol in $\mathrm{CH}_{2} \mathrm{Cl}_{2}$ (+ TMU) gave a mixture of epoxy compound $\mathbf{4 a}(60-70 \%)$ and bromide 5a $(30-40 \%)$. In 5a, the oxirane ring was opened by nucleophilic $\mathrm{Br}^{-}$ions produced by $\mathrm{Ph}_{3} \mathrm{P}$ and $\mathrm{CBr}_{4}$. Also in the DMFpromoted reaction, a mixture of $\mathbf{4 a}(70-90 \%)$ and $\mathbf{5 a}(10-30 \%)$ was derived. In both reaction pathways, however, the glycosylation was $\alpha$-selective $(\alpha: \beta \geq 90: 10$, yields $>80 \%)$ and not accompanied by isomerization at the glycerol moiety.

A mixture of $4 \mathbf{a}$ and $\mathbf{5 a}$ was used in the following chemical transformation (Scheme 2). First, a lyso-glycolipid 6a was derived after deprotection at the sugar hydroxymethyl position and $\mathrm{S}_{\mathrm{N}} 2$ substitution with cesium palmitate at the glycerol $s n-1$ position. Then, this compound was converted to glycolipid $\mathbf{8 a}$ after sequential reaction of the temporary tert-butyldimethylsilyl (TBDMS) -protected sugar, and O-acylation at the glycerol 2-OH position to give 7a, followed by removal of the TBDMS protecting group. For introducing the phosphocholine group at the sugar 6-OH position, we employed a phosphoroamidite method using $1 H$-tetrazole as a promoter [34]. First, 8 a was treated with 2-cyanoethyl- $N, N, N^{\prime}, N^{\prime}$-tetraisopropyl phosphorodiamidite in the presence of $1 H$-tetrazole, and then with choline tosylate to give 9a. After removal of the sugar $O$-benzyl group by catalytic hydrogenolysis, the GGPL-I homologue I-a was obtained. In the same way, the GGPL-I $s n$-isomer I-b was derived from a mixture of $\mathbf{4 b}$ and $\mathbf{5 b}$ available from the reaction between $\mathbf{1}$ and $(R)$-glycidol (Scheme 1 and Scheme 2b).

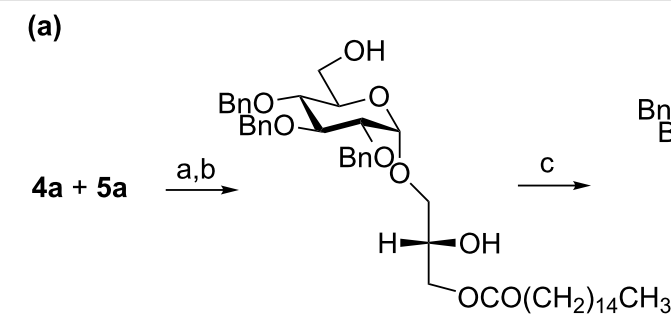

$6 \mathbf{a}$

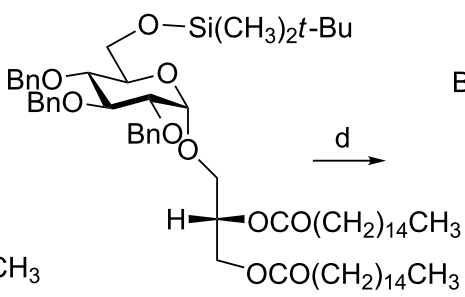

$7 a$

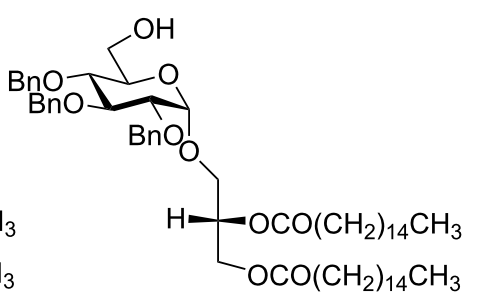

$8 \mathbf{a}$

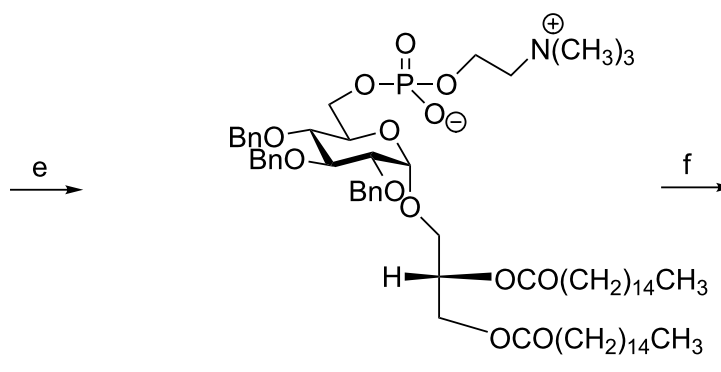

$9 \mathbf{a}$
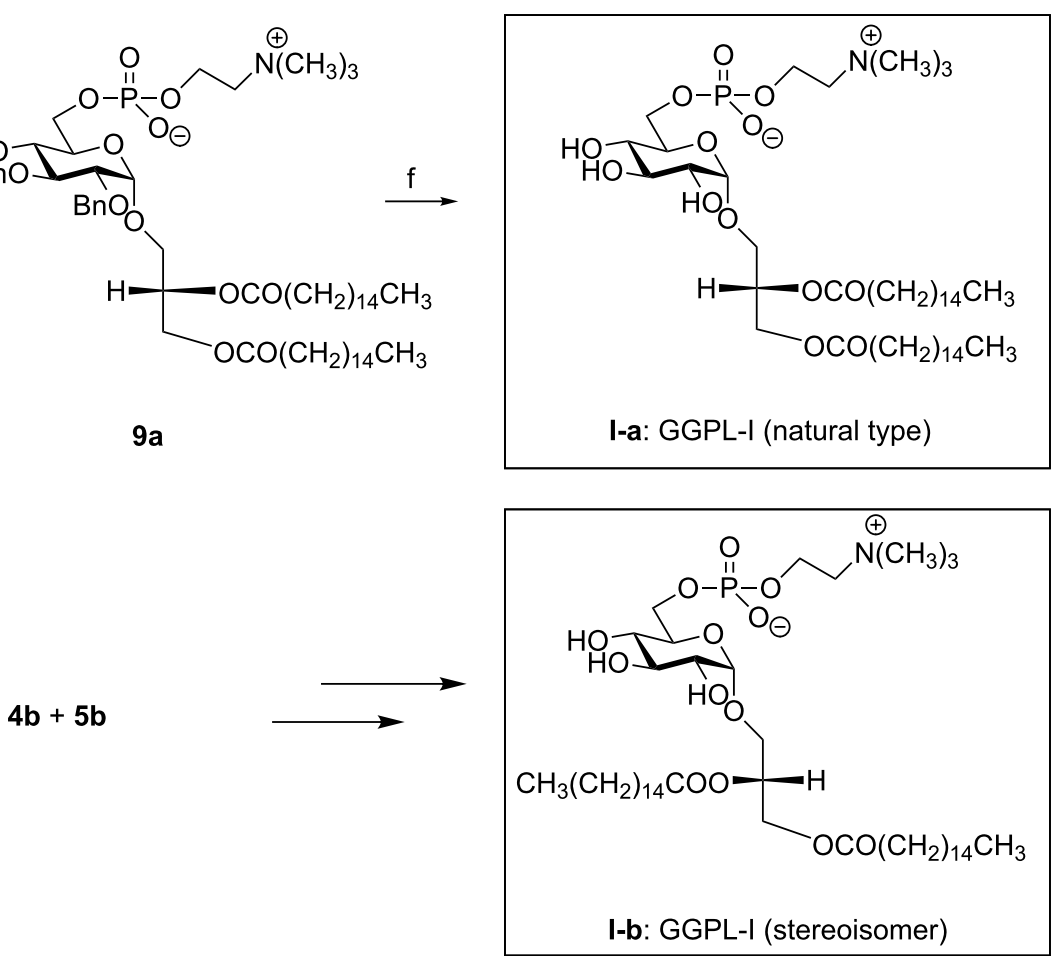

Scheme 2: Syntheses of GGPL-I homologue I-a and its isomer I-b. Conditions: (a) $\mathrm{K}_{2} \mathrm{CO}_{3}, \mathrm{CH}_{3} \mathrm{OH}$; (b) cesium palmitate in DMF; (c) TBDMS chloride then palmitoyl chloride in pyridine + DMAP; (d) TFA in $\mathrm{CH}_{3} \mathrm{OH}$; (e) (i) 2-cyanoethyl- $N, N, N^{\prime}, N^{\prime}$-tetraisopropyl phosphorodiamidite, $1 \mathrm{H}_{\text {-tetrazole and }}$ MS-4 $\AA$ in $\mathrm{CH}_{2} \mathrm{Cl}_{2}$; (ii) choline tosylate, $1 \mathrm{H}$-tetrazole, (iii) $m \mathrm{CPBA}$, (iv) aq. $\mathrm{NH}_{3}$ in $\mathrm{CH}_{3} \mathrm{OH}$, (f) $\mathrm{H}_{2}, \mathrm{Pd}(\mathrm{OH})_{2} / \mathrm{C}$ in $\mathrm{CH}_{3} \mathrm{OH}$. 


\section{${ }^{1} \mathrm{H}$ NMR characterization of $\mathbf{I}-\mathbf{a}, \mathbf{I}-\mathbf{b}$ and the related glycerolipids}

${ }^{1} \mathrm{H}$ NMR spectroscopy provides a useful tool for discriminating between the two GGPL-I isomers as shown in Figure 2. A clear difference was observed in the chemical shifts of the glycerol methylene protons as designated by "a" and "b". Conversely, little difference was observed between the $s n$-isomers at the sugar H-1 signal as well as at the glycerol H-2 (Table 1).
Natural GGPL-I and GGPL-III gave ${ }^{1} \mathrm{H}$ NMR data very close to those of $\mathbf{I}-\mathbf{a}$, indicating that both have a common skeleton of 3-O-( $\alpha$-D-glucopyranosyl)-sn-glycerol $[15,16]$.

The glycerol moiety has two $\mathrm{C}-\mathrm{C}$ single bonds. By free rotation, each of them is allowed to have three staggered conformers of $g g$ (gauche-gauche), gt (gauche-trans) and $t g$ (trans-gauche) (Figure 3). In solution and also in self-

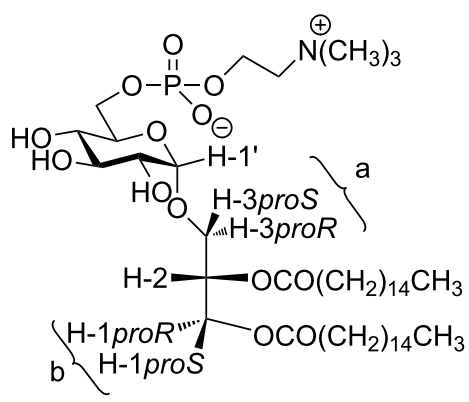

I-a: GGPL-I

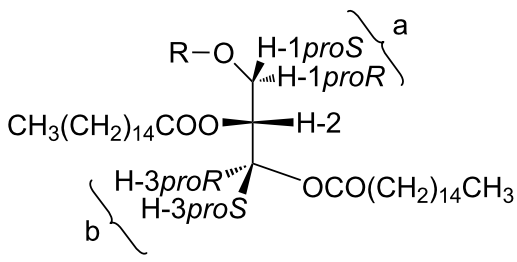

I-b: $s n$-isomer

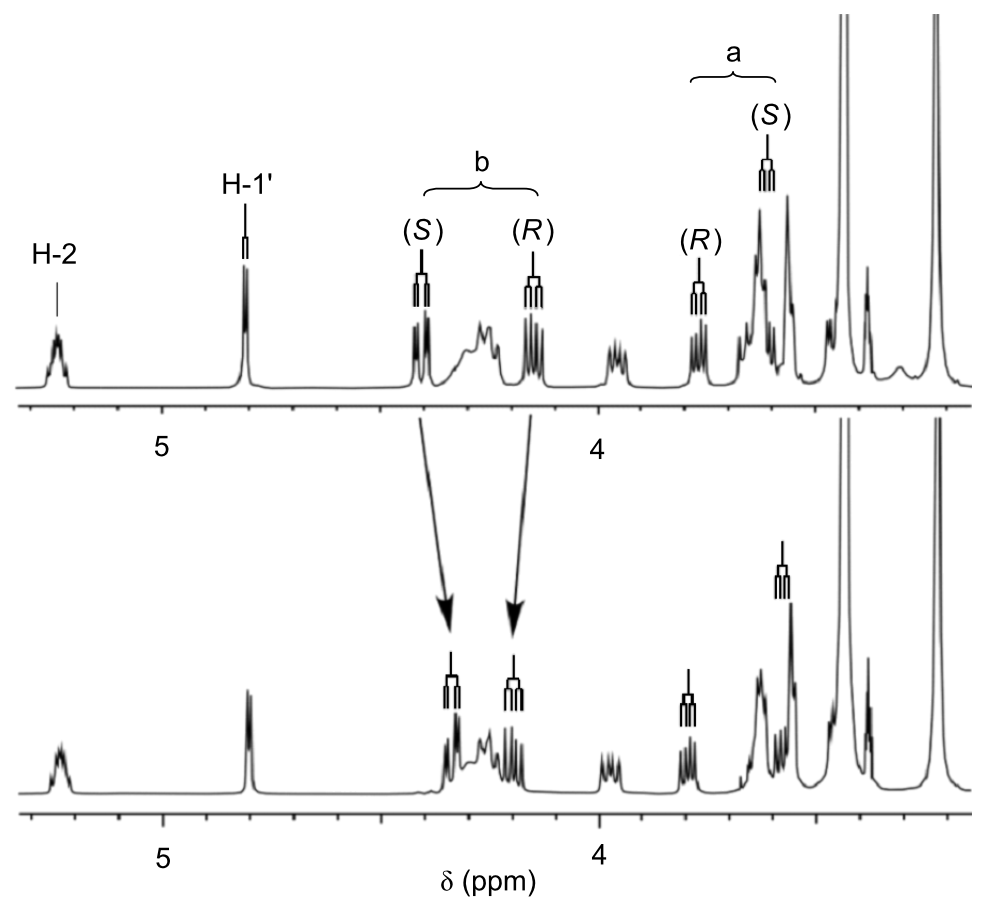

Figure 2: ${ }^{1} \mathrm{H} \mathrm{NMR}$ spectra of I-a and I-b $\left(500 \mathrm{MHz}, 25^{\circ} \mathrm{C}, \mathrm{CDCl}_{3} / \mathrm{CD}_{3} \mathrm{OD} 10: 1\right)$. The assignment of sn-glycerol methylene protons $\left(\mathrm{H}_{\text {proR }}\right.$ and $\left.\mathrm{H}_{\text {pros }}\right)$ was performed on the basis of our preceding studies on deuterium-labeled glycerols [35-37] and $\alpha(1 \rightarrow 6)$-linked disaccharides [38-40].

Table 1: ${ }^{1} \mathrm{H}$ NMR data $(500 \mathrm{MHz})$ of I-a, I-b, and their precursors (9a and $\mathbf{9 b}$ ).

$\delta[\mathrm{ppm}]\left({ }^{3} J\right.$ and $\left.{ }^{2} J[\mathrm{~Hz}]\right)$

Compound

glucose

$\mathrm{H}-1$

$-1$

$\mathrm{H}-1$

$\mathrm{H}-1$ pros

proR

$4.80(3.5)$

$4.14(6.5)$

$4.70(3.5)$

$4.17(6.5)$

$3.80(6.0)$

4.74 (3.5)

3.76 (5.5) sn-glycerol moiety

$\mathrm{H}-2$

-3 -3

pros

$3.61(5.5,11.0)$

$3.52(6.0,11.0)$

$4.20(6.5,12.0)$

$4.19(6.5,12.0)$

These $\alpha$-glycolipids were dissolved in a mixture of $\mathrm{CDCl}_{3}$ and $\mathrm{CD}_{3} \mathrm{OD}(10: 1)$ at $11.2 \mathrm{mM}$ concentration. 


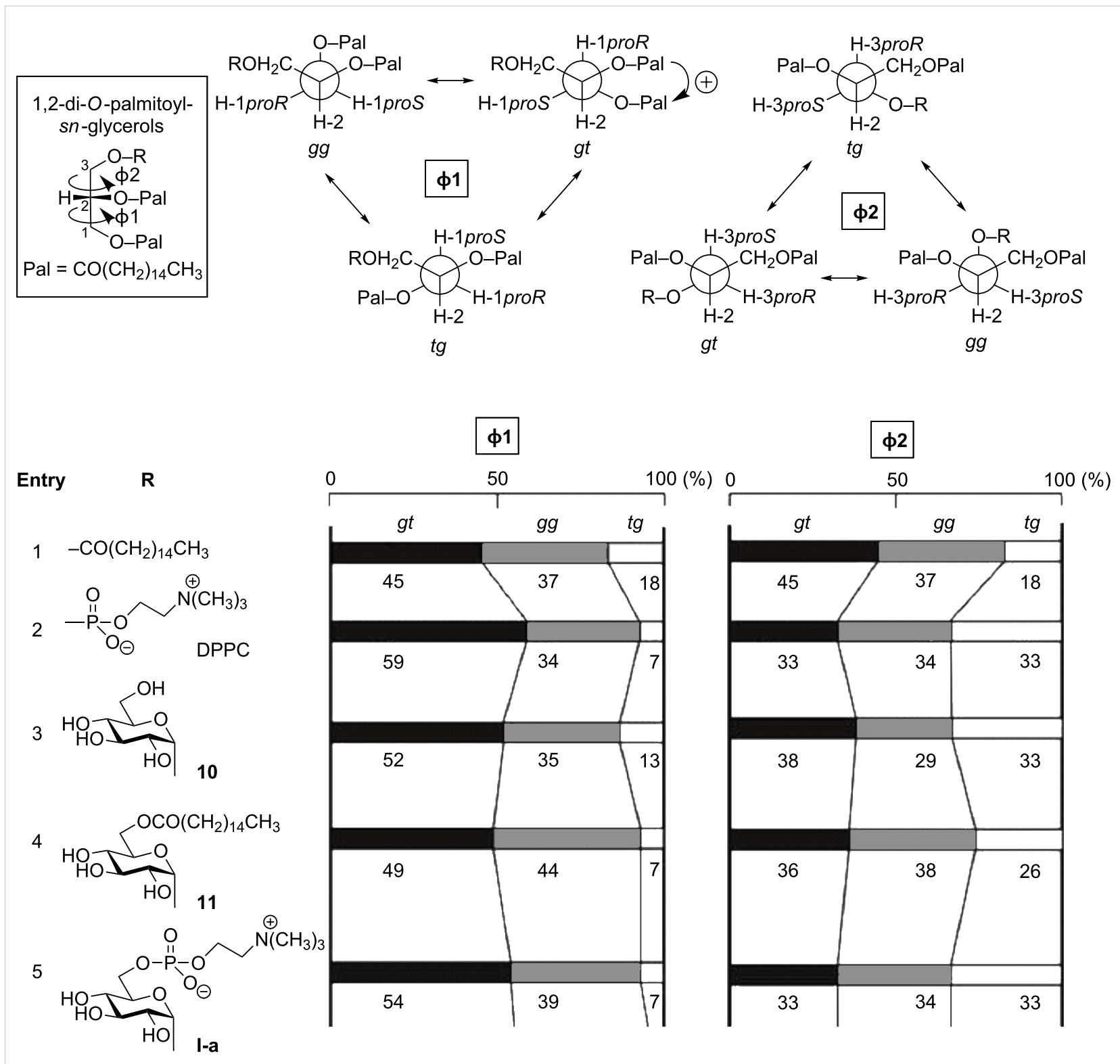

Figure 3: Distributions of $g g, g t$ and tg-conformers in 3-substituted sn-glycerols at $11 \mathrm{mM}$ in solutions of $\mathrm{CDCl}_{3}$ and $\mathrm{CD}_{3} \mathrm{OD}(10: 1)$ at $298 \mathrm{~K}$.

contacting liquid-crystalline states, these conformers are thought to equilibrate with each other. In this study, we calculated time-averaged populations of the three conformers by means of ${ }^{1} \mathrm{H}$ NMR spectroscopy. As we reported in a preceding paper [41], the Karplus-type equation proposed by Haasnoot et al.[42] was adapted as follows:

$2.8 g g+3.1 g t+10.7 t g={ }^{3} J_{\mathrm{H} 2, \mathrm{H} 1 \mathrm{~S}}\left(\right.$ or $\left.^{3} J_{\mathrm{H} 2, \mathrm{H} 3 \mathrm{R}}\right)$

$0.9 g g+10.7 g t+5.0 t g={ }^{3} J_{\mathrm{H} 2, \mathrm{H} 1 \mathrm{R}}\left(\right.$ or $\left.^{3} J_{\mathrm{H} 2, \mathrm{H} 3 \mathrm{~S}}\right)$ and

$g g+g t+\operatorname{tg}=1$.
In this equation, a perfect staggering ( $\Phi 1$ and $\Phi 2=+60,-60$ or 180 degree) is assumed for every conformer. Figure 3 summarizes the results for a series of 3-substituted 1,2-di- $O$-palmitoyl$s n$-glycerols, which involve tripalmitin (Figure 3, entry 1), DPPC (1,2-di-O-palmitoylphosphatidylcholine) (Figure 3, entry 2 ), and GGPL-I homologues (Figure 3, entries 3-5). In a solution state with a mixture of $\mathrm{CDCl}_{3}$ and $\mathrm{CD}_{3} \mathrm{OD}(10: 1)$ as the solvent and at a concentration of $11.2 \mathrm{mM}$, tripalmitin adopts the three conformers in the ratio of $g t(45 \%), g g(37 \%)$ and $t g$ $(18 \%)$. In comparison with this symmetric lipid, the asymmetric phospholipid (DPPC) favors the $g t$-conformer more strongly around the tail lipid moiety along the $s n-1,2$ position, while disfavoring the $t g$-conformer, in the ratio of $g t$ (59\%), $g g$ 

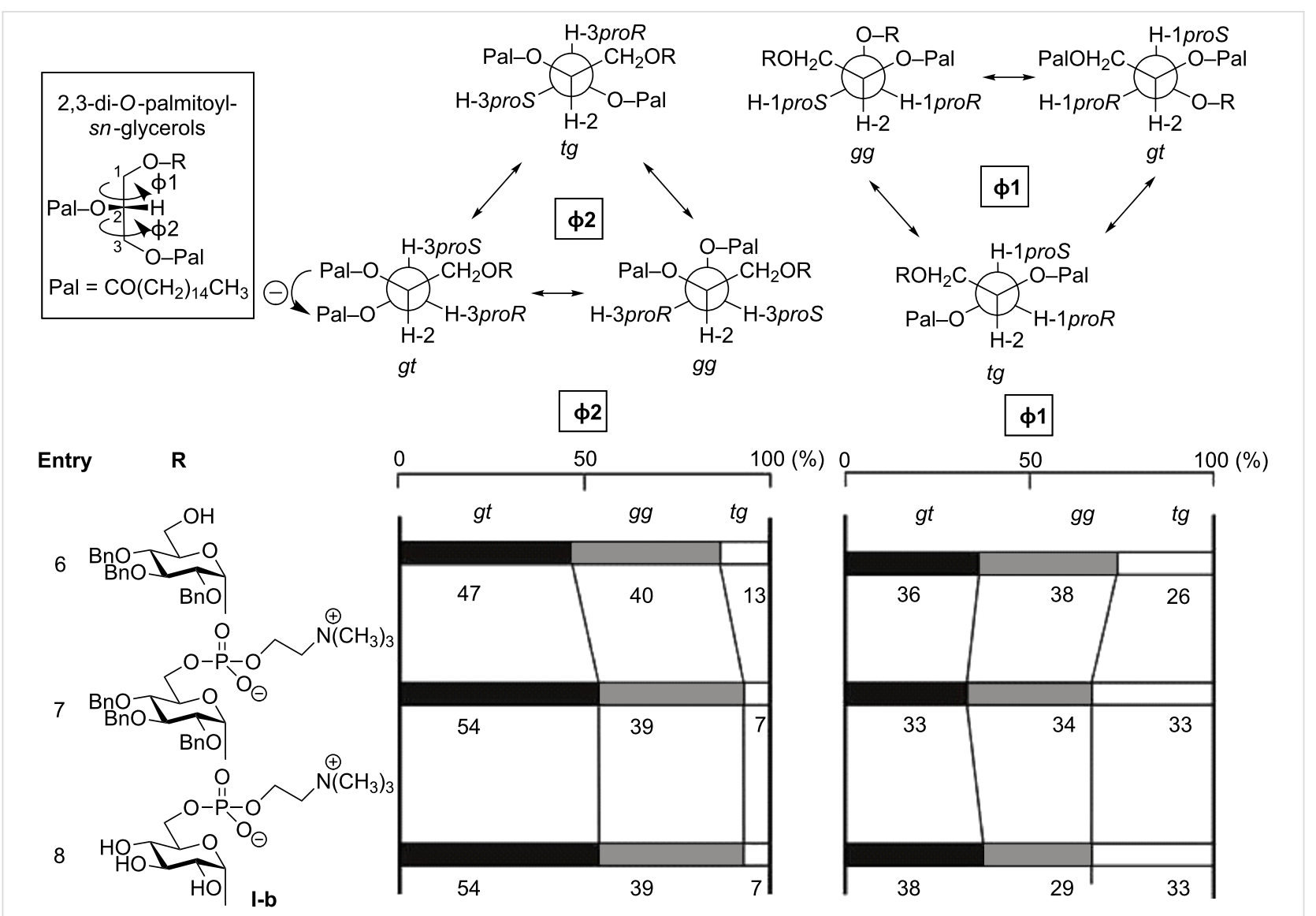

Figure 4: Distributions of $g g, g t$ and $t g$-conformers in 1-substituted sn-glycerols. In these sn-isomers, $\Phi 1$ and $\Phi 2$ represent the dihedral angles around the $\mathrm{C}-\mathrm{C}$ single bond at the glycerol $s n-2,3$ and 1,2-position, respectively.

(34\%) and $\operatorname{tg}(7 \%)$. The head phosphate moiety along the $s n-2,3$ position adopts the three conformers in equilibrated populations $(g g=g t=t g)$.

3-O-( $\alpha$-D-glucopyranosyl)-sn-glycerolipids 10 and 11 (Figure 3, entries 3 and 4) were found to have conformational properties very similar to DPPC; the lipid tail moiety prefers the gauche conformations ( $g t$ and $g g$ ), while the sugar moiety allows a random conformation. Here, it should be mentioned that the conformer distribution coincides between I-a (Figure 3, entry 5) and DPPC (Figure 3, entry 2) at the head moiety [ $g t$ (33\%), $g g(34 \%)$ and $\operatorname{tg}(33 \%)]$.

The above analysis was carried out also for the stereoisomer I-b and the related glycolipids (Figure 4, entries 6-8). The isomer (Figure 4, entry 8) showed an overall conformational property similar to I-a and DPPC (Figure 5), although a small difference was observed in the conformer distribution at the sugar head moiety. However, it should be recognized here that the helical direction (helicity) of the $g t$ conformer in I-b is reversed (anticlockwise) from the case of DPPC and GGPL-I (clockwise), as depicted in Figure 3 and Figure 4.
$\mathrm{R}=\alpha-\mathrm{Glc}$, phosphocholine, 6-O-phosphocholine- $\alpha$-Glc

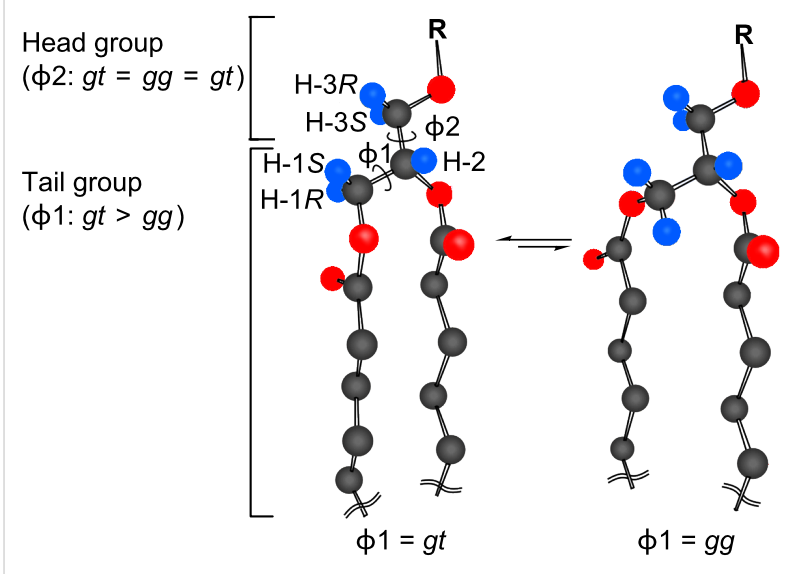

Figure 5: A common conformational property of GGPL-I and DPPC The tail lipid moiety favors two gauche-conformers of $g t$ and $g g$ (gt > $g g \gg>t g$ ), while the head moiety takes three conformers in averaged populations $(g t=g g=t g)$. 


\section{Conclusion}

We have proposed a synthetic pathway to a GGPL-I homologue and its stereoisomer, in which our one-pot $\alpha$-glycosylation methodology was effectively applied. We envisage that the simple method will allow us to prepare a variety of $\alpha$-glycolipid antigens other than GGPLs and to prove their biological significance [43]. By the ${ }^{1} \mathrm{H}$ NMR conformational analysis, which was based on our former studies on deuteriumlabeled $s n$-glycerols and sugars, we have proven that GGPL-I and other 3-O-( $\alpha$-D-glucopyranosyl)-sn-glycerolipids have a common conformational property at the chiral glycerol moiety: The lipid tail moiety prefers two gauche-conformations ( $g g$ and $g t$ ) in the order $g t>g g>>t g$, while the sugar head moiety adopts three conformers in an averaged population $(g g=g t=$ $t g$ ). At the lipid tail position, the $g t$-conformer with clockwise helicity is predominant over the anticlockwise $g g$-conformer. The observed conformation was very close to what we have seen in DPPC (Figure 5). Although these results were based on the solution state in a solvent mixture of $\mathrm{CHCl}_{3}$ and $\mathrm{CH}_{3} \mathrm{OH}$ $(10: 1)$, it may be possible to assume that the mycoplasma GGPLs and the related 3-O-( $\alpha$-D-glycopyranosyl)-sn-glycerolipids can constitute cytoplasm membranes in good cooperation with ubiquitous phospholipids without inducing stereochemical stress at the membrane.

The GGPL-I isomer I-b showed an overall conformational property similar to the natural isomer I-a and DPPC. However, it should be mentioned here that the chiral helicity of $g t$-conformers in I-b is reversed (anticlockwise) from the clockwise helicity of DPPC and GGPL-I. The difference in chirality seems critical in biological recognition events and also in physicochemical contact with other chiral constituents in cell membranes $[44,45]$.

\section{Experimental}

\section{General methods}

Infrared (IR) spectra were recorded on a JASCO FT/IR-230 Fourier transform infrared spectrometer on $\mathrm{KBr}$ disks. All ${ }^{1} \mathrm{H}$ NMR $(500 \mathrm{MHz})$ spectra were recorded by using a Varian INOVA-500 or Varian Gemini 200. ${ }^{1} \mathrm{H}$ chemical shifts are expressed in parts per million ( $\delta \mathrm{ppm})$ by using an internal standard of tetramethylsilane (TMS $=0.000 \mathrm{ppm}$ ). Mass spectra were recorded with a JEOL JMS 700 spectrometer for fast atom bombardment (FAB) spectra. Silica gel column chromatography was performed on silica gel 60 (Merck $0.063-0.200 \mathrm{~mm}$ and $0.040-0.063 \mathrm{~mm}$ ) and eluted with a mixture of toluene and ethyl acetate or a mixture of $\mathrm{CHCl}_{3}$ and $\mathrm{CH}_{3} \mathrm{OH}$ in gradient modes (100:0 to 80:20). For purification of phosphocholinecontaining products, a chromatographic column packed with Iatrobeads (IATRON LABORATORIES INC., 6RS-8060) was applied and eluted with a mixture of $\mathrm{CH}_{3} \mathrm{OH}$ and $\mathrm{CHCl}_{3}$ in gradient modes. For thin-layer chromatography (TLC) analysis, Merck precoated TLC plates (silica gel $60 \mathrm{~F}_{254}$, layer thickness $0.25 \mathrm{~mm}$ ) and Merck TLC aluminum roles (silica gel $60 \mathrm{~F}_{254}$, layer thickness $0.2 \mathrm{~mm}$ ) were used. All other chemicals were purchased from Tokyo Kasei Kogyo Co., Ltd., Kishida Chemical Co., Ltd., and Sigma-Aldrich Chemical Company Co, Int., and were used without further purification.

\section{A typical procedure for the one-pot $\alpha$-glycosylation: $\mathrm{CBr}_{4}$} (1.6 g, $6.09 \mathrm{mmol})$ and $\mathrm{Ph}_{3} \mathrm{P}(2.02 \mathrm{~g}, 6.09 \mathrm{mmol})$ were added to a solution of 6-O-acetyl-2,3,4-tri- $O$-benzyl-D-glucose (1) (1.0 $\mathrm{g}, 2.03 \mathrm{mmol}$ ) in $10 \mathrm{~mL}$ of DMF and stirred for $3 \mathrm{~h}$ at $\mathrm{rt}$. Then, $(S)$-glycidol (301 $\mathrm{mg}, 4.06 \mathrm{mmol}$ ) was added to the reaction mixture and stirred for $14 \mathrm{~h}$ at $\mathrm{rt}$. Products were diluted with a mixture of toluene and ethyl acetate (10:1), and the solution was washed with saturated aq. $\mathrm{NaHCO}_{3}$ and aq. $\mathrm{NaCl}$ solution, dried and concentrated. The residue was purified by silica gel column chromatography in toluene and ethyl acetate to give a mixture of $4 \mathbf{a}$ and $5 \mathbf{a}$ (the ratio changed with reaction time) as colorless syrup. The total yield of $\mathbf{4 a}$ and $\mathbf{5 a}$ was between $80 \%$ and $90 \%$.

3-O-(2,3,4-tri- $O$-benzyl- $\alpha$-D-glucopyranosyl)-1,2-di- $O$ palmitoyl-sn-glycerols 8a and $8 \mathbf{b}: \mathrm{K}_{2} \mathrm{CO}_{3}(379 \mathrm{mg}$, $2.74 \mathrm{mmol})$ was added to the mixture of $4 \mathbf{a}$ and $5 \mathbf{a}(1 \mathrm{~g}$, $1.83 \mathrm{mmol}$ based on $4 a)$ in $\mathrm{CH}_{3} \mathrm{OH}(20 \mathrm{~mL})$ and stirred for $1 \mathrm{~h}$ at $\mathrm{rt}$. The reaction mixture was neutralized, washed with water, dried, and concentrated. The residue was dried under reduced pressure and directly subjected to the next reaction. A mixture of caesium palmitate $(2.7 \mathrm{~g}, 7.3 \mathrm{mmol})$ in DMF $(40 \mathrm{~mL})$ was heated at $100-110^{\circ} \mathrm{C}$, to which the DMF solution of the above residue was added slowly. The reaction mixture was stirred for $2 \mathrm{~h}$ at $110^{\circ} \mathrm{C}$, cooled to $\mathrm{rt}$, and then filtered through a pad of Celite powder with ethyl acetate. The filtrate was washed with saturated aq. $\mathrm{NaCl}$ solution, dried, and concentrated. The residue was purified by silica gel column chromatography to give $\mathbf{6 a}$ as a colorless syrup ( $830 \mathrm{mg}, 60 \%$ yield). To a solution of $6 \mathbf{a}(300 \mathrm{mg}, 0.39 \mathrm{mmol})$ in pyridine $(20 \mathrm{~mL})$, TBDMS chloride $(107 \mathrm{mg}, 0.71 \mathrm{mmol})$ and $4-N, N$-dimethylaminopyridine (cat.) were added. The reaction mixture was stirred for $12 \mathrm{~h}$ at $\mathrm{rt}$, treated with methanol $(2 \mathrm{~mL})$ for $3 \mathrm{~h}$ and concentrated. The residue was purified by silica gel column chromatography in a mixture of toluene and ethyl acetate. The main product was dissolved in pyridine $(20 \mathrm{~mL})$ and then reacted with palmitoyl chloride (162 mg, $0.59 \mathrm{mmol}$ ) for $3 \mathrm{~h}$ at $\mathrm{rt}$. The reaction mixture was treated with methanol $(2 \mathrm{~mL})$ and then concentrated with toluene. The residue was dissolved in a mixture of $\mathrm{CH}_{3} \mathrm{OH}$ and $\mathrm{CH}_{2} \mathrm{Cl}_{2}(1: 1,20 \mathrm{~mL})$ and treated with trifluoroacetic acid $(1 \mathrm{~mL})$ for $2 \mathrm{~h}$ at $\mathrm{rt}$. After concentration, the residue was purified by silica gel column chromatography in a mixture of toluene and ethyl acetate to give $\mathbf{8 a}$ as a white waxy solid 
(0.32 g, 81\% yield from 6a). $[\alpha]_{\mathrm{D}}{ }^{30}+21.1\left(c\right.$ 1.0, $\left.\mathrm{CHCl}_{3}\right)$; IR (KBr, film): 3413, 2923, 2853, 1736, 1630, 1457, 1361, 1158, $1069,736 \mathrm{~cm}^{-1} ;{ }^{1} \mathrm{H} \mathrm{NMR}\left(500 \mathrm{MHz}, \mathrm{CDCl}_{3}\right): \delta_{\mathrm{H}} 7.40-7.23$ $\left(\mathrm{m}, 5 \mathrm{H} \times 3,-\mathrm{CH}_{2} \mathrm{C}_{6} \mathrm{H}_{5}\right), 5.23(\mathrm{~m}, 1 \mathrm{H}$, glycerol H-2), 4.96-4.64 $\left(\mathrm{d}, 2 \mathrm{H} \times 3,-\mathrm{CH}_{2} \mathrm{C}_{6} \mathrm{H}_{5}\right), 4.70(\mathrm{~d}, 1 \mathrm{H}, J=3.5 \mathrm{~Hz}, \mathrm{H}-1), 4.40$ (dd, $1 \mathrm{H}, J=4.0$ and $12.0 \mathrm{~Hz}$, glycerol $\left.\mathrm{H}-1_{\mathrm{proS}}\right), 4.19(\mathrm{dd}, 1 \mathrm{H}, J=$ 6.0 and $12.0 \mathrm{~Hz}$, glycerol $\left.\mathrm{H}-1_{\mathrm{proR}}\right), 3.96(\mathrm{dd}, 1 \mathrm{H}, J=9.5$ and $9.5 \mathrm{~Hz}, \mathrm{H}-3), 3.72(\mathrm{dd}, 1 \mathrm{H}, J=5.5$ and $10.5 \mathrm{~Hz}$, glycerol $\mathrm{H}-3_{\text {proR }}$ ), 3.72 and 3.66 (b, 2H, H- 6 ProR and H- $\left.6_{\text {pros }}\right), 3.65$ (m, $1 \mathrm{H}, \mathrm{H}-5), 3.54$ (dd, $1 \mathrm{H}, J=5.5$ and $10.5 \mathrm{~Hz}$, glycerol $\mathrm{H}-3_{\text {proS }}$ ), $3.50(\mathrm{dd}, 1 \mathrm{H}, J=9.5$ and $10.0 \mathrm{~Hz}, \mathrm{H}-4), 3.49$ $(\mathrm{dd}, 1 \mathrm{H}, J=3.5$ and $9.5 \mathrm{~Hz}, \mathrm{H}-2), 2.29(\mathrm{~m}, 2 \mathrm{H} \times 2$, $\left.-\mathrm{OCOCH}_{2} \mathrm{CH}_{2}\left(\mathrm{CH}_{2}\right)_{12} \mathrm{CH}_{3}\right), 1.58$ (b, $2 \mathrm{H} \times 2$, $\left.-\mathrm{OCOCH}_{2} \mathrm{CH}_{2}\left(\mathrm{CH}_{2}\right)_{12} \mathrm{CH}_{3}\right), 1.25$ (b, $24 \mathrm{H} \times 2$, $\left.-\mathrm{OCOCH}_{2} \mathrm{CH}_{2}\left(\mathrm{CH}_{2}\right)_{12} \mathrm{CH}_{3}\right), 0.88(\mathrm{t}, 3 \mathrm{H} \times 2, J=7.0 \mathrm{~Hz}$, $\left.-\mathrm{OCOCH}_{2} \mathrm{CH}_{2}\left(\mathrm{CH}_{2}\right)_{12} \mathrm{CH}_{3}\right)$; FABMS $m / z$ : $[\mathrm{M}+\mathrm{Na}]^{+} 1023.7$.

In the same way as derived for the synthesis of $\mathbf{8 a},(R)$-glycidol and $\mathbf{6 b}(0.30 \mathrm{~g}, 0.39 \mathrm{mmol})$ was used for the synthesis of $\mathbf{8 b}$ (0.30 g, 77\% yield). $[\alpha]_{\mathrm{D}}{ }^{32}+18.5\left(c 1.0, \mathrm{CHCl}_{3}\right)$; IR $(\mathrm{KBr}$, film): 3452, 2924, 2854, 1739, 1586, 1455, 1296, 1159, 1095, $710 \mathrm{~cm}^{-1} ;{ }^{1} \mathrm{H}$ NMR $\left(500 \mathrm{MHz}, \mathrm{CDCl}_{3}\right): \delta_{\mathrm{H}} 7.40-7.23(\mathrm{~m}, 5 \mathrm{H} \times$ $\left.3,-\mathrm{CH}_{2} \mathrm{C}_{6} \mathrm{H}_{5}\right), 5.23(\mathrm{~b}, 1 \mathrm{H}$, glycerol H-2), 4.96-4.63 (d, $2 \mathrm{H} \times$ $3,-\mathrm{CH}_{2} \mathrm{C}_{6} \mathrm{H}_{5}$ ), 4.75 (d, $\left.1 \mathrm{H}, J=3.5 \mathrm{~Hz}, \mathrm{H}-1\right), 4.38$ (dd, $1 \mathrm{H}, J=$ 3.5 and $12.0 \mathrm{~Hz}$, glycerol $\mathrm{H}-3$ proR $), 4.21(\mathrm{dd}, 1 \mathrm{H}, J=6.5$ and $12.0 \mathrm{~Hz}$, glycerol $\left.\mathrm{H}-3_{\mathrm{proS}}\right), 3.96(\mathrm{dd}, 1 \mathrm{H}, J=9.5$ and $9.5 \mathrm{~Hz}$, $\mathrm{H}-3), 3.73\left(\mathrm{dd}, 1 \mathrm{H}, J=6.0\right.$ and $11.0 \mathrm{~Hz}$, glycerol $\left.\mathrm{H}-1_{\mathrm{proS}}\right), 3.76$

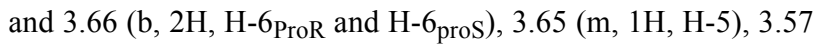
(dd, $1 \mathrm{H}, J=5.5$ and $11.0 \mathrm{~Hz}$, glycerol $\left.\mathrm{H}-1_{\text {proR }}\right), 3.51(\mathrm{dd}, 1 \mathrm{H}, J$ $=9.5$ and $10.0 \mathrm{~Hz}, \mathrm{H}-4), 3.50(\mathrm{dd}, 1 \mathrm{H}, J=3.5$ and $9.5 \mathrm{~Hz}, \mathrm{H}-2)$, $2.29\left(\mathrm{~b}, 2 \mathrm{H} \times 2,-\mathrm{OCOCH}_{2} \mathrm{CH}_{2}\left(\mathrm{CH}_{2}\right)_{12} \mathrm{CH}_{3}\right), 1.59(\mathrm{~b}, 2 \mathrm{H} \times 2$, $\left.-\mathrm{OCOCH}_{2} \mathrm{CH}_{2}\left(\mathrm{CH}_{2}\right)_{12} \mathrm{CH}_{3}\right), 1.25$ (b, $24 \mathrm{H} \times 2$, $\left.-\mathrm{OCOCH}_{2} \mathrm{CH}_{2}\left(\mathrm{CH}_{2}\right)_{12} \mathrm{CH}_{3}\right), 0.88(\mathrm{t}, 3 \mathrm{H} \times 2, J=7.0 \mathrm{~Hz}$, $\left.-\mathrm{OCOCH}_{2} \mathrm{CH}_{2}\left(\mathrm{CH}_{2}\right)_{12} \mathrm{CH}_{3}\right)$; FABMS $m / z$ : $[\mathrm{M}+\mathrm{Na}]^{+} 1023.7$.

\section{A phosphorodiamidite method for the syn- thesis of I-a}

(a) The reaction vessel was kept under anhydrous conditions with Ar gas in the presence of molecular sieves $(50 \% \mathrm{w} / \mathrm{w})$, and a solution of $8 \mathbf{a}(0.20 \mathrm{~g}, 0.20 \mathrm{mmol})$ and 2-cyanoethyl$N, N, N^{\prime}, N^{\prime}$-tetraisopropyl phosphorodiamidite $(90.4 \mathrm{mg}, 0.30$ mmol) in $10 \mathrm{~mL}$ of $\mathrm{CH}_{2} \mathrm{Cl}_{2}$ was injected. $1 \mathrm{H}$-tetrazole $(28.4$ $\mathrm{mg}, 0.40 \mathrm{mmol})$ was added and stirred for $2 \mathrm{~h}$ at $\mathrm{rt}$. Then $1 H$-tetrazole (42.6 mg, $0.60 \mathrm{mmol}, 3.0$ equiv) and choline tosylate $(220.3 \mathrm{mg}, 0.8 \mathrm{mmol}$ : thoroughly dried overnight under vacuum) were added to the reaction mixture and stirred for $1.5 \mathrm{~h}$ at $\mathrm{rt}$. The reaction was quenched by the addition of water $(1 \mathrm{~mL})$, and then $m$-chloroperbenzoic acid $(51.8 \mathrm{mg}, 0.3 \mathrm{mmol})$ was added at $0{ }^{\circ} \mathrm{C}$ and stirred for $10 \mathrm{~min}$ at rt. The reaction mixture was washed with $10 \%$ aq. $\mathrm{Na}_{2} \mathrm{SO}_{3}$ solution, saturated aq. $\mathrm{NaHCO}_{3}$ solution, water and saturated aq. $\mathrm{NaCl}$ solution, dried and concentrated. The residue was dissolved in a mixture of $\mathrm{CH}_{3} \mathrm{OH}(10 \mathrm{~mL})$ and $30 \%$ aq. $\mathrm{NH}_{3}(1 \mathrm{~mL})$ and stirred for $15 \mathrm{~min}$ at $\mathrm{rt}$. The reaction mixture was concentrated, and the residue was purified by column chromatography (IATROBEADS in a mixture of $\mathrm{CHCl}_{3}$ and $\mathrm{CH}_{3} \mathrm{OH}$ ) to give 9a (186 mg, 80\% yield). $[\alpha]_{\mathrm{D}}{ }^{26}+13.0\left(c 0.45, \mathrm{CHCl}_{3}\right)$; IR ( $\mathrm{KBr}$, film): 3301, 2929, 2856, 2537, 1731, 1577, 1419, 1216, 1093, 925, 788, 746; ${ }^{1} \mathrm{H}$ NMR $\left(500 \mathrm{MHz}, \mathrm{CDCl}_{3}\right): \delta_{\mathrm{H}} 7.35-7.25(\mathrm{~m}$, $\left.5 \mathrm{H} \times 3,-\mathrm{CH}_{2} \mathrm{C}_{6} H_{5}\right), 5.22(\mathrm{~m}, 1 \mathrm{H}$, glycerol H-2), 4.93-4.61 (d, $\left.2 \mathrm{H} \times 3,-\mathrm{CH}_{2} \mathrm{C}_{6} \mathrm{H}_{5}\right), 4.70(\mathrm{~d}, 1 \mathrm{H}, J=3.5 \mathrm{~Hz}, \mathrm{H}-1), 4.38(\mathrm{dd}$, $1 \mathrm{H}, J=3.0$ and $12.0 \mathrm{~Hz}$, glycerol $\left.\mathrm{H}-1_{\text {pros }}\right), 4.19$ (b, $2 \mathrm{H}$, choline $\left.-\mathrm{CH}_{2} \mathrm{CH}_{2} \mathrm{~N}^{+}\left(\mathrm{CH}_{3}\right)_{3}\right), 4.17(\mathrm{dd}, 1 \mathrm{H}, J=6.5$ and $12.0 \mathrm{~Hz}$, glycerol H- $\left.1_{\text {proR }}\right), 4.15$ and $4.02\left(\mathrm{~m}, 2 \mathrm{H} \times 2, \mathrm{H}-6_{\mathrm{ProR}}\right.$ and $\left.\mathrm{H}-6_{\text {proS }}\right)$, $3.93(\mathrm{dd}, 1 \mathrm{H}, J=9.0$ and $9.5 \mathrm{~Hz}, \mathrm{H}-3), 3.72(\mathrm{dd}, 1 \mathrm{H}, J=5.5$ and $11.0 \mathrm{~Hz}$, glycerol H-3 proR), $3.71(\mathrm{~b}, 1 \mathrm{H}, \mathrm{H}-5), 3.62(\mathrm{t}, 1 \mathrm{H}$, $\mathrm{H}-4), 3.58\left(\mathrm{~b}, 2 \mathrm{H}\right.$, choline $\left.-\mathrm{CH}_{2} \mathrm{CH}_{2} \mathrm{~N}^{+}\left(\mathrm{CH}_{3}\right)_{3}\right), 3.52(\mathrm{dd}, 1 \mathrm{H}, J$ $=6.0$ and $11.0 \mathrm{~Hz}$, glycerol $\mathrm{H}-3$ pros $), 3.46(\mathrm{dd}, 1 \mathrm{H}, J=3.5$ and $9.5 \mathrm{~Hz}, \mathrm{H}-2), 3.15\left(\mathrm{~s}, 9 \mathrm{H},-\mathrm{POCH}_{2} \mathrm{CH}_{2} \mathrm{~N}^{+}\left(\mathrm{CH}_{3}\right)_{3}\right)$, $2.28\left(\mathrm{~m}, 2 \mathrm{H} \times 2,-\mathrm{OCOCH}_{2} \mathrm{CH}_{2}\left(\mathrm{CH}_{2}\right)_{12} \mathrm{CH}_{3}\right), 1.58(\mathrm{~b}, 2 \mathrm{H} \times 2$, $\left.-\mathrm{OCOCH}_{2} \mathrm{CH}_{2}\left(\mathrm{CH}_{2}\right)_{12} \mathrm{CH}_{3}\right), 1.25$ (b, $24 \mathrm{H} \times 2$, $\left.-\mathrm{OCOCH}_{2} \mathrm{CH}_{2}\left(\mathrm{CH}_{2}\right)_{12} \mathrm{CH}_{3}\right), 0.88(\mathrm{t}, 3 \mathrm{H} \times 2, J=7.0 \mathrm{~Hz}$, $\left.-\mathrm{OCOCH}_{2} \mathrm{CH}_{2}\left(\mathrm{CH}_{2}\right)_{12} \mathrm{CH}_{3}\right)$; FABMS $m / z$ : $[\mathrm{M}+\mathrm{Na}]^{+} 1188.7$.

(b) Compound 9a $(0.18 \mathrm{~g}, 0.15 \mathrm{mmol})$ was hydrogenated with $\mathrm{Pd}(\mathrm{OH})_{2} / \mathrm{C}(8 \mathrm{mg})$ under atmospheric pressure in a mixture of $\mathrm{CH}_{3} \mathrm{OH}(10 \mathrm{~mL})$ and acetic acid $(0.1 \mathrm{~mL})$ for $7 \mathrm{~h}$ at $\mathrm{rt}$. The reaction mixture was neutralized by the addition of $\mathrm{Et}_{3} \mathrm{~N}$, filtered and concentrated. The residue was purified by column chromatography with IATROBEADS $\left(\mathrm{CH}_{3} \mathrm{OH}\right.$ and $\left.\mathrm{CHCl}_{3}\right)$ to give I-a (101 mg, 75\% yield). $[\alpha]_{\mathrm{D}}{ }^{31}+18.7$ (c 1.0, $\mathrm{CHCl}_{3} /$

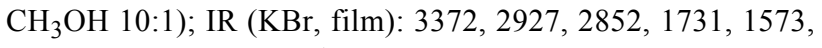
1469, 1112, 975, 727; ${ }^{1} \mathrm{H}$ NMR (500 MHz, $\mathrm{CDCl}_{3} / \mathrm{CD}_{3} \mathrm{OD}$ 10:1): $\delta_{\mathrm{H}} 5.23(\mathrm{~m}, 1 \mathrm{H}$, glycerol H-2), $4.80(\mathrm{~d}, 1 \mathrm{H}, J=3.5 \mathrm{~Hz}$, $\mathrm{H}-1), 4.39$ (dd, $1 \mathrm{H}, J=3.5$ and $12.0 \mathrm{~Hz}$, glycerol $\left.\mathrm{H}-1_{\text {pros }}\right), 4.30$ (b, $\left.2 \mathrm{H},-\mathrm{CH}_{2} \mathrm{CH}_{2} \mathrm{~N}^{+}\left(\mathrm{CH}_{3}\right)_{3}\right), 4.24$ and 3.95 (b, 2H, H-6 ProR and H-6 $\left.6_{\text {proS }}\right), 4.14$ (dd, $1 \mathrm{H}, J=6.5$ and $12.0 \mathrm{~Hz}$, glycerol H-1 $1_{\text {proR }}$ ), $3.75(\mathrm{dd}, 1 \mathrm{H}, J=5.5$ and $11.0 \mathrm{~Hz}$, glycerol H-3 proR), 3.67 (b, $2 \mathrm{H}$, choline- $\left.\mathrm{CH}_{2} \mathrm{CH}_{2} \mathrm{~N}^{+}\left(\mathrm{CH}_{3}\right)_{3}\right), 3.65(\mathrm{~b}, 1 \mathrm{H} \times 2, \mathrm{H}-3$ and $\mathrm{H}-5)$, $3.61(\mathrm{dd}, 1 \mathrm{H}, J=5.5$ and $11.0 \mathrm{~Hz}$, glycerol $\mathrm{H}-3$ pros $)$, $3.56(\mathrm{~b}, 1 \mathrm{H}, \mathrm{H}-4), 3.46(\mathrm{~b}, 1 \mathrm{H}, \mathrm{H}-2), 3.22(\mathrm{~s}, 9 \mathrm{H}$, $\left.-\mathrm{POCH}_{2} \mathrm{CH}_{2} \mathrm{~N}^{+}\left(\mathrm{CH}_{3}\right)_{3}\right), 2.31 \quad(\mathrm{~m}, 2 \mathrm{H} \times 2$, $\left.-\mathrm{OCOCH}_{2} \mathrm{CH}_{2}\left(\mathrm{CH}_{2}\right)_{12} \mathrm{CH}_{3}\right), 1.60$ (b, $2 \mathrm{H} \times 2$, $\left.-\mathrm{OCOCH}_{2} \mathrm{CH}_{2}\left(\mathrm{CH}_{2}\right)_{12} \mathrm{CH}_{3}\right), 1.25$ (b, $24 \mathrm{H} \times 2$, $\left.-\mathrm{OCOCH}_{2} \mathrm{CH}_{2}\left(\mathrm{CH}_{2}\right)_{12} \mathrm{CH}_{3}\right), 0.88(\mathrm{t}, 3 \mathrm{H} \times 2, J=7.0 \mathrm{~Hz}$, $\left.-\mathrm{OCOCH}_{2} \mathrm{CH}_{2}\left(\mathrm{CH}_{2}\right)_{12} \mathrm{CH}_{3}\right)$; HRMS-FAB $(\mathrm{m} / \mathrm{z})$ : $[\mathrm{M}+\mathrm{Na}]^{+}$ calcd for $\mathrm{C}_{46} \mathrm{H}_{90} \mathrm{NO}_{13} \mathrm{PNa}, 918.6048$; found, 918.6028.

In the same way as described above, $9 \mathbf{b}(180 \mathrm{mg})$ was derived from $\mathbf{8 b}$ (200 $\mathrm{mg}, 0.20 \mathrm{mmol})$ in $76 \%$ yield and converted to the GGPL-I isomer I-b [70 mg, 81\% yield from $\mathbf{9 b}(120 \mathrm{mg})]$. 9b: $[\alpha]_{\mathrm{D}}{ }^{26}+8.1\left(c 0.62, \mathrm{CHCl}_{3}\right)$; IR (KBr, film): 3413, 2923, 2857 , 
1735, 1461, 1241, 1097, 744, 495, 445; ${ }^{1} \mathrm{H}$ NMR $(500 \mathrm{MHz}$, $\left.\mathrm{CDCl}_{3}\right): \delta_{\mathrm{H}} 7.35-7.23\left(\mathrm{~m}, 5 \mathrm{H} \times 3,-\mathrm{CH}_{2} \mathrm{C}_{6} H_{5}\right), 5.23(\mathrm{~b}, 1 \mathrm{H}$, glycerol H-2), 4.94-4.64 (d, $\left.2 \mathrm{H} \times 3,-\mathrm{CH}_{2} \mathrm{C}_{6} \mathrm{H}_{5}\right), 4.74(\mathrm{~d}, 1 \mathrm{H}, J$ $=3.5 \mathrm{~Hz}, \mathrm{H}-1), 4.37(\mathrm{dd}, 1 \mathrm{H}, J=3.0$ and $12.0 \mathrm{~Hz}$, glycerol $\mathrm{H}-3$ proR), 4.23 (b, $2 \mathrm{H}$, choline- $\left.\mathrm{CH}_{2} \mathrm{CH}_{2} \mathrm{~N}^{+}\left(\mathrm{CH}_{3}\right)_{3}\right), 4.19$ (dd, $1 \mathrm{H}, J=6.5$ and $12.0 \mathrm{~Hz}$, glycerol $\mathrm{H}-3_{\text {pros }}$ ), 4.16 and 4.09 (b, $2 \mathrm{H}, \mathrm{H}-6_{\text {proR }}$ and $\left.\mathrm{H}-6_{\text {pros }}\right), 3.94(\mathrm{dd}, 1 \mathrm{H}, J=9.5$ and $9.5 \mathrm{~Hz}$, $\mathrm{H}-3), 3.76\left(\mathrm{dd}, 1 \mathrm{H}, J=5.5\right.$ and $11.0 \mathrm{~Hz}$, glycerol $\left.\mathrm{H}-1_{\text {pros }}\right), 3.72$ (m, 1H, H-5), 3.61 (dd, 1H, $J=9.0$ and $9.5 \mathrm{~Hz}, \mathrm{H}-4), 3.60$ (b, $2 \mathrm{H}$, choline- $\left.\mathrm{CH}_{2} \mathrm{CH}_{2} \mathrm{~N}^{+}\left(\mathrm{CH}_{3}\right)_{3}\right), 3.57(\mathrm{dd}, 1 \mathrm{H}, J=5.5$ and 11.0 $\mathrm{Hz}$, glycerol $\left.\mathrm{H}-1_{\text {proR }}\right), 3.49$ (dd, $1 \mathrm{H}, J=3.5$ and $\left.9.5 \mathrm{~Hz}, \mathrm{H}-2\right)$, $3.20\left(\mathrm{~s}, 9 \mathrm{H}\right.$, choline- $\left.\mathrm{CH}_{2} \mathrm{CH}_{2} \mathrm{~N}^{+}\left(\mathrm{CH}_{3}\right)_{3}\right), 2.28(\mathrm{dd}, 2 \mathrm{H} \times 2, J=$ 7.5 and $\left.15 \mathrm{~Hz},-\mathrm{OCOCH}_{2} \mathrm{CH}_{2}\left(\mathrm{CH}_{2}\right)_{12} \mathrm{CH}_{3}\right), 1.58(\mathrm{~b}, 2 \mathrm{H} \times 2$, $\left.-\mathrm{OCOCH}_{2} \mathrm{CH}_{2}\left(\mathrm{CH}_{2}\right)_{12} \mathrm{CH}_{3}\right), 1.25$ (b, $24 \mathrm{H} \times 2$, $\left.-\mathrm{OCOCH}_{2} \mathrm{CH}_{2}\left(\mathrm{CH}_{2}\right)_{12} \mathrm{CH}_{3}\right), 0.88(\mathrm{t}, 3 \mathrm{H} \times 2, J=7.0 \mathrm{~Hz}$, $\left.-\mathrm{OCOCH}_{2} \mathrm{CH}_{2}\left(\mathrm{CH}_{2}\right)_{12} \mathrm{CH}_{3}\right)$; FABMS $m / z$ : $[\mathrm{M}+\mathrm{Na}]^{+} 1188.7$. I-b: $[\alpha]_{\mathrm{D}}{ }^{31}=+10.7\left(c 1.0, \mathrm{CHCl}_{3} / \mathrm{CH}_{3} \mathrm{OH} 10: 1\right)$; IR (KBr film): 3390, 2919, 2856, 1731, 1463, 1228, 1074, 964, 711; ${ }^{1} \mathrm{H}$ NMR $\left(500 \mathrm{MHz}, \mathrm{CDCl}_{3} / \mathrm{CD}_{3} \mathrm{OD} 10: 1\right): \delta_{\mathrm{H}} 5.24(\mathrm{~m}, 1 \mathrm{H}$, glycerol $\mathrm{H}-2), 4.80(\mathrm{~d}, 1 \mathrm{H}, J=3.5 \mathrm{~Hz}, \mathrm{H}-1), 4.34$ (dd, $1 \mathrm{H}, J=3.5$ and $12.0 \mathrm{~Hz}$, glycerol H-3 proR), 4.28 (b, 2H, choline$\left.\mathrm{CH}_{2} \mathrm{CH}_{2} \mathrm{~N}^{+}\left(\mathrm{CH}_{3}\right)_{3}\right), 4.25$ and 3.97 (b, 2H, H-6 ProR and $\left.\mathrm{H}-6_{\text {proS }}\right), 4.20\left(\mathrm{dd}, 1 \mathrm{H}, J=7.0\right.$ and $12.0 \mathrm{~Hz}$, glycerol $\left.\mathrm{H}-3_{\text {proS }}\right)$, $3.80\left(\mathrm{dd}, 1 \mathrm{H}, J=6.0\right.$ and $11.0 \mathrm{~Hz}$, glycerol $\left.\mathrm{H}-1_{\text {proS }}\right), 3.63(\mathrm{~b}$, $1 \mathrm{H} \times 2, \mathrm{H}-3$ and $\mathrm{H}-5), 3.63\left(\mathrm{~b}, 2 \mathrm{H}\right.$, choline $\left.-\mathrm{CH}_{2} \mathrm{CH}_{2} \mathrm{~N}^{+}\left(\mathrm{CH}_{3}\right)_{3}\right)$, $3.58\left(\mathrm{dd}, 1 \mathrm{H}, J=5.5\right.$ and $11.0 \mathrm{~Hz}$, glycerol $\left.\mathrm{H}-1_{\text {proR }}\right), 3.55$ (b, $1 \mathrm{H}, \mathrm{H}-4), 3.46(\mathrm{dd}, 1 \mathrm{H}, \mathrm{H}-2), 3.22$ (s, 9H, choline$\left.\mathrm{CH}_{2} \mathrm{CH}_{2} \mathrm{~N}^{+}\left(\mathrm{CH}_{3}\right)_{3}\right), 2.31(\mathrm{dd}, 2 \mathrm{H} \times 2, J=7.5$ and $15 \mathrm{~Hz}$, $\left.-\mathrm{OCOCH}_{2} \mathrm{CH}_{2}\left(\mathrm{CH}_{2}\right)_{12} \mathrm{CH}_{3}\right), 1.60$ (b, $2 \mathrm{H} \times 2$, $\left.-\mathrm{OCOCH}_{2} \mathrm{CH}_{2}\left(\mathrm{CH}_{2}\right)_{12} \mathrm{CH}_{3}\right), 1.26(\mathrm{~b}, 24 \mathrm{H} \times 2$, $\left.-\mathrm{OCOCH}_{2} \mathrm{CH}_{2}\left(\mathrm{CH}_{2}\right)_{12} \mathrm{CH}_{3}\right), 0.88(\mathrm{t}, 3 \mathrm{H} \times 2, J=7.0 \mathrm{~Hz}$, $\left.-\mathrm{OCOCH}_{2} \mathrm{CH}_{2}\left(\mathrm{CH}_{2}\right)_{12} \mathrm{CH}_{3}\right)$; HRMS-FAB $\left.(\mathrm{m} / \mathrm{z}): \mathrm{M}+\mathrm{Na}\right]^{+}$ calcd for $\mathrm{C}_{46} \mathrm{H}_{90} \mathrm{NO}_{13} \mathrm{PNa}, 918.6048$; found, 918.6078.

3-O-( $\alpha$-D-glucopyranosyl)-1,2-di- $O$-palmitoyl-sn-glycerol (10, entry 3): Compound 10 was obtained as a waxy solid (73 $\mathrm{mg}, 83 \%$ yield $)$ from $\mathbf{8 a}(120 \mathrm{mg}, 0.12 \mathrm{mmol})$ by catalytic hydrogenation under the same reaction conditions as those described above for the preparation of $\mathbf{I}-\mathbf{a}$. $[\alpha]_{\mathrm{D}}{ }^{30}+27.2(c$ 1.0, $\mathrm{CHCl}_{3} / \mathrm{CH}_{3} \mathrm{OH} 10: 1$ ); IR (KBr, film): 3411, 2919, 2851, 1739 , 1587, 1465, 1158, 1053, $720 \mathrm{~cm}^{-1}$; ${ }^{1} \mathrm{H}$ NMR $(500 \mathrm{MHz}$, $\left.\mathrm{CDCl}_{3} / \mathrm{CD}_{3} \mathrm{OD} 10: 1\right): \delta_{\mathrm{H}} 5.25(\mathrm{~m}, 1 \mathrm{H}$, glycerol H-2), $4.83(\mathrm{~d}$, $1 \mathrm{H}, J=3.5 \mathrm{~Hz}, \mathrm{H}-1), 4.40(\mathrm{dd}, 1 \mathrm{H}, J=3.5$ and $12.0 \mathrm{~Hz}$, glycerol H-1 $\left.{ }_{\text {pros }}\right), 4.16(\mathrm{dd}, 1 \mathrm{H}, J=6.5$ and $12.0 \mathrm{~Hz}$, glycerol $\left.\mathrm{H}-1_{\text {proR }}\right), 3.82\left(\mathrm{dd}, 1 \mathrm{H}, J=5.5\right.$ and $10.5 \mathrm{~Hz}$, glycerol $\left.\mathrm{H}-3_{\text {proR }}\right)$, $3.78\left(\mathrm{~d}, 2 \mathrm{H}, J=3.5 \mathrm{~Hz}, \mathrm{H}-6_{\text {proR }}\right.$ and $\left.\mathrm{H}-6_{\text {pros }}\right), 3.65$ (t, $1 \mathrm{H}, J=$ 9.5 and $9.5 \mathrm{~Hz}, \mathrm{H}-3), 3.62(\mathrm{dd}, 1 \mathrm{H}, J=6.0$ and $10.5 \mathrm{~Hz}$, glycerol H-3 $\mathrm{proS}), 3.56$ (dt, 1H, H-5), 3.44 (dd, $1 \mathrm{H}, J=3.5$ and 9.5 $\mathrm{Hz}, \mathrm{H}-2), 3.42(\mathrm{dd}, 1 \mathrm{H}, J=8.5$ and $10.0 \mathrm{~Hz}, \mathrm{H}-4), 2.32$ (dt, $\left.2 \mathrm{H} \times 2,-\mathrm{OCOCH}_{2} \mathrm{CH}_{2}\left(\mathrm{CH}_{2}\right)_{12} \mathrm{CH}_{3}\right), 1.61(\mathrm{~b}, 2 \mathrm{H} \times 2$, $\left.-\mathrm{OCOCH}_{2} \mathrm{CH}_{2}\left(\mathrm{CH}_{2}\right)_{12} \mathrm{CH}_{3}\right), 1.26$ (b, $24 \mathrm{H} \times 2$,
$\left.-\mathrm{OCOCH}_{2} \mathrm{CH}_{2}\left(\mathrm{CH}_{2}\right)_{12} \mathrm{CH}_{3}\right), 0.88(\mathrm{t}, 3 \mathrm{H} \times 2, J=7.0 \mathrm{~Hz}$, $\left.-\mathrm{OCOCH}_{2} \mathrm{CH}_{2}\left(\mathrm{CH}_{2}\right)_{12} \mathrm{CH}_{3}\right)$; HRMS-FAB $(\mathrm{m} / \mathrm{z})$ : [M + $\mathrm{Na}]^{+}$calcd for $\mathrm{C}_{41} \mathrm{H}_{78} \mathrm{O}_{10} \mathrm{Na}, 753.5493$; found, 753.5519 .

\section{3-O-(6-O-palmitoyl- $\alpha$-D-glucopyranosyl)-1,2-di- $O$-palmi-} toyl-sn-glycerol (11, entry 4): A mixture of 8a (120 mg, 0.12 mmol) and palmitoyl chloride ( $165 \mathrm{mg}, 0.6 \mathrm{mmol})$ in pyridine was stirred at $\mathrm{rt}$ for $3 \mathrm{~h}$ and then treated with $\mathrm{CH}_{3} \mathrm{OH}(1 \mathrm{~mL})$ for $3 \mathrm{~h}$. After concentration in vacuo, the residue was purified on silica gel (toluene/ethyl acetate). The main product (138 mg) was dissolved in a mixture of cyclohexene/ethanol 1:4 and subjected to catalytic hydrogenation at atmospheric pressure in the presence of $\mathrm{Pd}(\mathrm{OH})_{2} / \mathrm{C}(50 \mathrm{mg})$. The product was purified by silica gel column chromatography $\left(\mathrm{CH}_{3} \mathrm{OH} / \mathrm{CHCl}_{3}\right)$ to afford 11 (99 mg, 85\% yield from 8a). $[\alpha]_{\mathrm{D}}{ }^{30}+20.9$ (c 1.0, $\mathrm{CHCl}_{3} /$ $\mathrm{CH}_{3} \mathrm{OH} 10: 1$ ); IR (KBr, film): 3414, 2919, 2851, 1739, 1605, 1465, 1375, 1176, 1054, $720 \mathrm{~cm}^{-1} ;{ }^{1} \mathrm{H}$ NMR $(500 \mathrm{MHz}$, $\left.\mathrm{CDCl}_{3} / \mathrm{CD}_{3} \mathrm{OD} 10: 1\right): \delta_{\mathrm{H}} 5.25(\mathrm{~m}, 1 \mathrm{H}$, glycerol H-2), $4.82(\mathrm{~d}$, $1 \mathrm{H}, J=4.0 \mathrm{~Hz}, \mathrm{H}-1), 4.40(\mathrm{dd}, 1 \mathrm{H}, J=3.5$ and $12.0 \mathrm{~Hz}$, glycer$\left.\mathrm{ol} \mathrm{H}-1_{\text {pros }}\right), 4.34$ and $4.30(\mathrm{dd} \times 2,2 \mathrm{H}, J=5.0$ and $12.0,2.5$ and $12.0 \mathrm{~Hz}, \mathrm{H}-6_{\text {proR }}$ and H-6 pros $), 4.16(\mathrm{dd}, 1 \mathrm{H}, J=6.5$ and 12.0 $\mathrm{Hz}$, glycerol $\left.\mathrm{H}-1_{\mathrm{proR}}\right), 3.82(\mathrm{dd}, 1 \mathrm{H}, J=5.0$ and $10.5 \mathrm{~Hz}$, glycerol H-3 $3_{\text {proR }}$ ), 3.73 (m, 1H, H-5), 3.65 (dd, 1H, $J=9.0$ and 9.5 $\mathrm{Hz}, \mathrm{H}-3), 3.61$ (dd, $1 \mathrm{H}, J=5.5$ and $10.5 \mathrm{~Hz}$, glycerol $\mathrm{H}-3_{\text {proS }}$ ), $3.45(\mathrm{dd}, 1 \mathrm{H}, J=4.0$ and $9.5 \mathrm{~Hz}, \mathrm{H}-2), 3.33(\mathrm{dd}$, $1 \mathrm{H}, J=9.0$ and $10.0 \mathrm{~Hz}, \mathrm{H}-4), 2.33(\mathrm{~m}, 2 \mathrm{H} \times 3$, $\left.-\mathrm{OCOCH}_{2} \mathrm{CH}_{2}\left(\mathrm{CH}_{2}\right)_{12} \mathrm{CH}_{3}\right), 1.61$ (b, $2 \mathrm{H} \times 3$, $\left.-\mathrm{OCOCH}_{2} \mathrm{CH}_{2}\left(\mathrm{CH}_{2}\right)_{12} \mathrm{CH}_{3}\right), 1.26$ (b, $24 \mathrm{H} \times 3$, $\left.-\mathrm{OCOCH}_{2} \mathrm{CH}_{2}\left(\mathrm{CH}_{2}\right)_{12} \mathrm{CH}_{3}\right), 0.88(\mathrm{t}, 3 \mathrm{H} \times 3, J=7.0 \mathrm{~Hz}$, -OCOCH $\left.\mathrm{CH}_{2}\left(\mathrm{CH}_{2}\right)_{12} \mathrm{CH}_{3}\right)$; HRMS-FAB $(\mathrm{m} / \mathrm{z})$ : $[\mathrm{M}+\mathrm{Na}]^{+}$ calcd for $\mathrm{C}_{57} \mathrm{H}_{108} \mathrm{O}_{11} \mathrm{Na}$, 991.7789; found, 991.7832.

\section{Acknowledgements}

This work was supported by the Industrial Technology Research Grant Program from New Energy and Industrial Technology Development Organization (NEDO) of Japan and from the Science \& Technology Project for a Safe \& Secure Society from the Ministry of Education, Culture, Sports, Science and Technology (MEXT) of Japan.

\section{References}

1. Rawadi, G. Microbes Infect. 2000, 2, 955-964. doi:10.1016/S1286-4579(00)00395-6

2. Shimizu, T.; Kida, Y.; Kuwano, K. Immunology 2004, 113, 121-129. doi:10.1111/j.1365-2567.2004.01937.x

3. Romero, F.; Moreno, E.; Ruiz-Bravo, A.; Jiménez-Valera, M. Curr. Microbiol. 2004, 48, 237-239. doi:10.1007/s00284-003-4134-1

4. Rottem, S. Biochim. Biophys. Acta, Rev. Biomembr. 1980, 604, 65-90. doi:10.1016/0005-2736(80)90585-4

5. Boggs, J. M. Biochim. Biophys. Acta 1987, 906, 353-404. 
6. Toujima, S.; Kuwano, K.; Zhang, Y.; Fujimoto, N.; Hirama, M.; Oishi, T.; Fukuda, S.; Nagumo, Y.; Imai, H.; Kikuchi, T.; Arai, S. Microbiology (Reading, U. K.) 2000, 146, 2317-2323.

7. Matsuda, K.; Kasama, T.; Ishizuka, I.; Handa, S.; Yamamoto, N.; Taki, T. J. Biol. Chem. 1994, 269, 33123-33128.

8. Matsuda, K.; Li, J.-L.; Harasawa, R.; Yamamoto, N. Biochem. Biophys. Res. Commun. 1997, 233, 644-649. doi:10.1006/bbrc.1997.6443

9. Li, J.-L.; Matsuda, K.; Takagi, M.; Yamamoto, N. J. Immunol. Methods 1997, 208, 103-113. doi:10.1016/S0022-1759(97)00135-X,

10. Matsuda, K.; Li, J.-L.; Ichinose, S.; Harasawa, R.; Saito, M.; Yamamoto, N. Microbiol. Immunol. 2000, 44, 695-702.

11. Zähringer, U.; Wagner, F.; Rietschel, E. T.; Ben-Menachem, G.; Deutsch, J.; Rottem, S. J. Biol. Chem. 1997, 272, 26262-26270. doi:10.1074/jbc.272.42.26262

12. Ben-Menachem, G.; Byström, T.; Rechnitzer, H.; Rottem, S.; Rilfors, L.; Lindblom, G. Eur. J. Biochem. 2001, 268, 3694-3701. doi:10.1046/j.1432-1327.2001.02277.x

13. Brandenburg, K.; Wagner, F.; Müller, M.; Heine, H.; Andrä, J.; Koch, M. H. J.; Zähringer, U.; Seydel, U. Eur. J. Biochem. 2003, 270, 3271-3279. doi:10.1046/j.1432-1033.2003.03719.x

14. Yavlovich, A.; Katzenell, A.; Tarshis, M.; Higazi, A. A.-R.; Rottem, S. Infect. Immun. 2004, 72, 5004-5011. doi:10.1128/IAI.72.9.5004-5011.2004

15. Nishida, Y.; Ohrui, H.; Meguro, H.; Ishizawa, M.; Matsuda, K.; Taki, T.; Handa, S.; Yamamoto, N. Tetrahedron Lett. 1994, 35, 5465-5468. doi:10.1016/S0040-4039(00)73526-X

16. Nishida, Y.; Takamori, Y.; Ohrui, H.; Ishizaka, I.; Matsuda, K.; Kobayashi, K. Tetrahedron Lett. 1999, 40, 2371-2374. doi:10.1016/S0040-4039(99)00191-4

17. Matsuda, K. Phosphocholine-containing glycoglycerolipids of Mycoplasma fermentans as a pathogen of rheumatoid arthritis: possible role of Mycoplasma fermentans GGPLs in the pathogenesis of neuroendocrine-immune abnormalities.. In Recent research developments in neuroscience; Pandalai, S. G., Ed.; Research Signpost: India, 2004; Vol. 1, pp 15-23.

18. Kawahito, Y.; Ichinose, S.; Sano, H.; Tsubouchi, Y.; Kohno, M.; Yoshikawa, T.; Tokunaga, D.; Hojo, T.; Harasawa, R.; Nakano, T.; Matsuda, K. Biochem. Biophys. Res. Commun. 2008, 369, 561-566. doi:10.1016/j.bbrc.2008.02.079

19. Sato, N.; Oizumi, T.; Kinbara, M.; Sato, T.; Funayama, H.; Sato, S.; Matsuda, K.; Takada, H.; Sugawara, S.; Endo, Y. FEMS Immunol. Med. Microbiol. 2010, 59, 33-41. doi:10.1111/j.1574-695X.2010.00657.x

20. Fujiwara, M.; Ishida, N.; Asano, K.; Matsuda, K.; Nomura, N.; Nishida, Y.; Harasawa, R. J. Vet. Med. Sci. 2010, 72, 805-808. doi:10.1292/jvms.09-0572

21. Ishida, N.; Irikura, D.; Matsuda, K.; Sato, S.; Sone, T.; Tanaka, M.; Asano, K. Curr. Microbiol. 2009, 58, 535-540. doi:10.1007/s00284-009-9362-6

22. Ishida, N.; Irikura, D.; Matsuda, K.; Sato, S.; Sone, T.; Tanaka, M.; Asano, K. J. Biosci. Bioeng. 2010, 109, 341-345. doi:10.1016/j.jbiosc.2009.09.049

23. Shingu, Y.; Nishida, Y.; Dohi, H.; Matsuda, K.; Kobayashi, K. J. Carbohydr. Chem. 2002, 21, 605-611. doi:10.1081/CAR-120016858

24. Shingu, Y.; Nishida, Y.; Dohi, H.; Kobayashi, K. Org. Biomol. Chem. 2003, 1, 2518-2521. doi:10.1039/b303984f

25. Nishida, Y.; Shingu, Y.; Dohi, H.; Kobayashi, K. Org. Lett. 2003, 5, 2377-2380. doi:10.1021/ol034269+
26. Shingu, Y.; Miyachi, A.; Miura, Y.; Kobayashi, K.; Nishida, Y. Carbohydr. Res. 2005, 340, 2236-2244. doi:10.1016/j.carres.2005.07.020

27. Gigg, R.; Penglis, A. A. E.; Conant, R. J. Chem. Soc., Perkin Trans. 1 1977, 2014-2017. doi:10.1039/P19770002014

28. Mannock, D. A.; Lewis, R. N.; McElhaney, R. N. Chem. Phys. Lipids 1990, 55, 309-321. doi:10.1016/0009-3084(90)90169-R

29. Gordon, D. M.; Danishefsky, S. J. J. Am. Chem. Soc. 1992, 114, 659-663. doi:10.1021/ja00028a036

30. Imai, H.; Oishi, T.; Kikuchi, T.; Hirama, M. Tetrahedron 2000, 56, 8451-8459. doi:10.1016/S0040-4020(00)00793-6

31. Shvets, V. I.; Bashkatova, A. I.; Evstigneeva, R. P. Chem. Phys. Lipids 1973, 10, 267-285. doi:10.1016/0009-3084(73)90006-6 And see the related references cited therein.

32. Lemieux, R. U.; Hendriks, K. B.; Stick, R. V.; James, K. J. Am. Chem. Soc. 1975, 97, 4056-4062. doi:10.1021/ja00847a032

33. Lu, S.-R.; Lay, Y.-H.; Chen, J.-H.; Liu, C.-Y.; Mong, K.-K. T. Angew. Chem. 2011, 123, 7453-7458. doi:10.1002/ange.201100076 And see the related references cited therein.

34. Hayakawa, Y.; Kataoka, M. J. Am. Chem. Soc. 1997, 119, 11758-11762. doi:10.1021/ja970685b

35. Nishida, Y.; Uzawa, H.; Hanada, S.; Ohrui, H.; Meguro, H. Agric. Biol. Chem. 1989, 53, 2319-2326. doi:10.1271/bbb1961.53.2319

36. Uzawa, H.; Nishida, Y.; Hanada, S.; Ohrui, H.; Meguro, H. J. Chem. Soc., Chem. Commun. 1989, 862-863. doi:10.1039/C39890000862

37. Uzawa, H.; Nishida, Y.; Ohrui, H.; Meguro, H. J. Org. Chem. 1990, 55, 116-122. doi:10.1021/jo00288a024

38. Ohrui, H.; Nishida, Y.; Watanabe, M.; Hori, H.; Meguro, H. Tetrahedron Lett. 1985, 26, 3251-3254. doi:10.1016/S0040-4039(00)98164-4

39. Nishida, Y.; Hori, H.; Ohrui, H.; Meguro, H.; Uzawa, J.; Reimer, D.; Sinnwell, V.; Paulsen, H. Tetrahedron Lett. 1988, 29, 4461-4464. doi:10.1016/S0040-4039(00)80522-5

40. Hori, H.; Nishida, Y.; Ohrui, H.; Meguro, H.; Uzawa, J. Tetrahedron Lett. 1988, 29, 4457-4460. doi:10.1016/S0040-4039(00)80521-3

41. Nishida, Y.; Hori, H.; Ohrui, H.; Meguro, H. J. Carbohydr. Chem. 1988, 7, 239-250. doi:10.1080/07328308808058917

42. Haasnoot, C. A. G.; de Leeuw, F. A. A. M.; Altona, C. Tetrahedron 1980, 36, 2783-2790. doi:10.1016/0040-4020(80)80155-4

43. Matsuda, K. Antigens: Lipids. In Encyclopedia of Life Science; John Wiley and Sons: Chichester, U. K., 2002; pp. 748-755.

44. Koynova, R. D.; Kuttenreich, H. L.; Tenchov, B. G.; Hinz, H. J. Biochemistry 1988, 27, 4612-4619. doi:10.1021/bi00413a005

45. Mannock, D. A.; Lewis, R. N.; McElhaney, R. N.; Akiyama, M.; Yamada, H.; Turner, D. C.; Gruner, S. M. Biophys. J. 1992, 63, 1355-1368. doi:10.1016/S0006-3495(92)81713-7 


\section{License and Terms}

This is an Open Access article under the terms of the Creative Commons Attribution License

(http://creativecommons.org/licenses/by/2.0), which permits unrestricted use, distribution, and reproduction in any medium, provided the original work is properly cited.

The license is subject to the Beilstein Journal of Organic Chemistry terms and conditions:

(http://www.beilstein-journals.org/bjoc)

The definitive version of this article is the electronic one which can be found at:

doi:10.3762/bjoc. 8.70 